\title{
Effectiveness of phosphodiesterase-5 inhibitor therapy for portopulmonary hypertension
}

\author{
Jolene $\mathrm{H}$ Fisher $\mathrm{MD}^{1,2}$, Sindhu R Johnson MD PhD ${ }^{1,3}$, Cathy Chau BMath ${ }^{3}$, Amie T Kron ${ }^{3}$, John T Granton MD ${ }^{1,2}$
}

\begin{abstract}
JH Fisher, SR Johnson, C Chau, AT Kron, JT Granton. Effectiveness of phosphodiesterase-5 inhibitor therapy for portopulmonary hypertension. Can Respir J 2015;22(1):42-46.
\end{abstract}

BACKGROUND: Portopulmonary hypertension is associated with significant morbidity and mortality. Phosphodiesterase-5 inhibitor therapy is efficacious in other causes of WHO group I pulmonary arterial hypertension. OBJECTIVE: To evaluate the efficacy and safety of phosphodiesterase-5 inhibitor therapy in patients with portopulmonary hypertension.

METHODS: A single-centre retrospective cohort study that included patients with a diagnosis of portopulmonary hypertension was performed. The primary outcome was change in pulmonary vascular resistance after six months of phosphodiesterase- 5 inhibitor therapy. A secondary evaluation investigated the effect on other hemodynamic measurements, 6 min walk distance, functional class, safety outcomes and survival.

RESULTS: Of 1385 patients screened, 25 patients with portopulmonary hypertension were identified, of whom 20 received a phosphodiesterase-5 inhibitor. After six months, there was a significant decrease in pulmonary vascular resistance $\left(-236 \mathrm{dyn} \cdot \mathrm{s} \cdot \mathrm{cm}^{-5}\left[95 \% \mathrm{CI}-343 \mathrm{dyn} \cdot \mathrm{s} \cdot \mathrm{cm}^{-5}\right.\right.$ to $-130 \mathrm{dyn} \bullet \mathrm{s} \cdot \mathrm{cm}^{-5}$ ]; $\left.\mathrm{P}<0.001\right)$, mean pulmonary artery pressure $(-8.9 \mathrm{mmHg}$ [95\% CI $-13.7 \mathrm{mmHg}$ to $-4.2 \mathrm{mmHg}$; $\mathrm{P}=0.001)$ and an increase in Fick cardiac output ( $0.9 \mathrm{~L} / \mathrm{min}[95 \% \mathrm{CI} 0.1 \mathrm{~L} / \mathrm{min}$ to $1.6 \mathrm{~L} / \mathrm{min}] ; \mathrm{P}=0.02)$. There was no change in 6 min walk distance. The proportion of subjects with a WHO functional class III or IV was significantly reduced at six months compared with baseline $(18 \%$ versus $61 \% ; \mathrm{P}=0.002)$. Safety outcomes did not reveal any adverse events.

CONCLUSIONS: Phosphodiesterase-5 inhibitor therapy improved hemodynamics and functional class at six months in a cohort of patients with portopulmonary hypertension.

Key Words: Phosphodiesterase inhibitors; Pulmonary hypertension; Pulmonary vascular resistance

P ortopulmonary hypertension ( $\mathrm{PoPH})$ is a serious complication of chronic liver disease that is associated with significant morbidity and mortality. $\mathrm{PoPH}$ is defined by the presence of pulmonary arterial hypertension (PAH) associated with portal hypertension in the absence of an alternative cause for PAH (1). PoPH is classified as 'group 1' pulmonary hypertension (2). This group includes other causes of PAH, including idiopathic, heritable and $\mathrm{PAH}$ due to drugs and connective tissue diseases (2). The pulmonary histopathological findings in PoPH and idiopathic PAH are identical (3). The median survival of untreated PoPH has been reported to be as low as six months (4). In fact, recently published United States registry data and previous retrospective cohort data demonstrated higher rates of death in patients with $\mathrm{PoPH}$ compared with those with idiopathic or heritable PAH $(5,6)$. Furthermore, the presence of severe PoPH has been shown to dramatically increase mortality post-liver transplant (7).

Several randomized control trials of targeted therapies, including prostaglandin analogues, endothelin-receptor antagonists and phosphodiesterase-5 (PDE5) inhibitors, have been shown to improve hemodynamics, exercise capacity, WHO functional class, quality of life and, in some instances, mortality in PAH (8-11). Sildenafil and

\author{
L'efficacité de l'inhibiteur de la phosphodiestérase \\ de type 5 contre l'hypertension portopulmonaire
}

HISTORIQUE : L'hypertension portopulmonaire s'associe à une morbidité et une mortalité importantes. L'inhibiteur de la phosphodiestérase de type 5 est efficace contre d'autres causes d'hypertension pulmonaire artérielle de groupe 1 selon la classification de l'OMS.

OBJECTIF : Évaluer l'efficacité et l'innocuité de l'inhibiteur de la phosphodiestérase de type 5 chez les patients faisant de l'hypertension pulmonaire.

MÉTHODOLOGIE : Des chercheurs ont effectué une étude rétrospective monocentrique de cohorte qui incluait des patients présentant une hypertension portopulmonaire diagnostiquée. Le résultat primaire était une modification de la résistance artérielle pulmonaire après la prise d'inhibiteur de la phosphodiestérase de type 5 pendant six mois. Une évaluation secondaire en évaluait l'effet sur d'autres mesures hémodynamiques, le test de marche de 6 minutes, la catégorie fonctionnelle, les résultats d'innocuité et la survie. RÉSULTATS : Des 1385 patients ayant subi un dépistage, 25 patients étaient atteints d'hypertension portopulmonaire, dont 20 ont reçu un inhibiteur de la phosphodiestérase de type 5 . Au bout de six mois, on a constaté une diminution importante de la résistance vasculaire pulmonaire $\left(-236 \mathrm{dyn} \cdot \mathrm{s} \cdot \mathrm{cm}^{-5}\left[95 \%\right.\right.$ IC $-343 \mathrm{dyn} \cdot \mathrm{s} \cdot \mathrm{cm}^{-5}$ à $\left.-130 \mathrm{dyn} \cdot \mathrm{s} \cdot \mathrm{cm}^{-5}\right]$; $\mathrm{P}<0,001)$, une tension artérielle pulmonaire moyenne $(-8,9 \mathrm{mmHg}[95 \%$ IC $-13,7 \mathrm{mmHg}$ à $-4,2 \mathrm{mmHg}$; $\mathrm{P}=0,001)$ et une augmentation du débit cardiaque selon le principe de Fick $(0,9 \mathrm{~L} / \mathrm{min}[95 \% \mathrm{IC} 0,1 \mathrm{~L} / \mathrm{min}$ à $1,6 \mathrm{~L} / \mathrm{min}]$; $\mathrm{P}=0,02)$. Il n'y avait pas de changement au test de marche de 6 minutes. La proportion de sujets ayant une classification fonctionnelle III ou IV de l'OMS avait considérablement diminué au bout de six mois (18\% par rapport à $61 \% ; \mathrm{P}=0,002)$. Les résultats d'innocuité n'ont révélé aucun événement indésirable.

CONCLUSIONS: L'inhibiteur de la phosphodiestérase de type 5 a amélioré l'hémodynamie et la catégorie fonctionnelle à six mois dans une cohorte de patients faisant de l'hypertension portopulmonaire.

tadalafil (two PDE5 inhibitors) have been shown to improve exercise capacity, WHO functional class and hemodynamics in randomized controlled trials involving patients with symptomatic PAH (11-13). However, patients with PoPH were excluded from these trials and the data available for targeted therapy in this group are limited. Accordingly, the objectives of the present study were to evaluate the effectiveness of PDE5 inhibitor monotherapy on pulmonary hemodynamics, symptoms and exercise capacity in a cohort of patients with PoPH.

\section{Patients}

\section{METHODS}

All patients followed at the University Health Network Pulmonary Hypertension Program (Toronto, Ontario) between 1998 and 2012 were screened for eligibility. Patients were included if they had a diagnosis of PAH, had a diagnosis of portal hypertension and were $\geq 18$ years of age at the time of diagnosis. The cohort was then subdivided into those treated with PDE5 inhibitors at any time after diagnosis and those not receiving PDE5 inhibitor therapy. PAH was defined as mean pulmonary artery pressure (mPAP) $\geq 25 \mathrm{mmHg}$ at rest, pulmonary

${ }^{1}$ University Health Network Pulmonary Hypertension Program; ${ }^{2}$ Division of Respirology, Department of Medicine, Toronto General Hospital;

${ }^{3}$ Division of Rheumatology, Department of Medicine, Toronto Western Hospital, Mount Sinai Hospital, University of Toronto, Toronto,

Ontario

Correspondence: Dr John T Granton, 11-1170 CSB, 585 University Avenue, Toronto, Ontario M5G 2 N2.

Telephone 416-340-4800 ext 5599, fax 416-340-3359, e-mail john.granton@uhn.ca 
capillary wedge pressure (PCWP) or left ventricular end-diastolic pressure $\leq 15 \mathrm{mmHg}$ (14), and pulmonary vascular resistance (PVR) $>240 \mathrm{dyn} \cdot \mathrm{s} \cdot \mathrm{cm}^{-5}$ on right heart catheterization. Given that volume overload can be present in cirrhotic patients, the transpulmonary gradient was used to determine the presence of PAH if the PCWP or left ventricular end-diastolic pressure was $>15 \mathrm{mmHg}$. A transpulmonary gradient $>12 \mathrm{mmHg}$ was chosen to indicate PAH (15). Portal hypertension was determined based on an abdominal ultrasound report specifically stating the presence of portal hypertension or esophageal varices observed on endoscopy. Patients were excluded from the present study if they: had another etiology for PAH (eg, HIV, anorexigen use, connective tissue disease, interstitial lung disease, severe chronic obstructive pulmonary disease or cardiac abnormalities); had another indication for PDE5 inhibitor use (eg, erectile dysfunction, Raynaud's phenomenon); or were $<18$ years of age. The study protocol was approved by the University Health Network Research Ethics Board (12-0082-AE).

\section{Exposure}

The exposure was treatment with PDE5 inhibitor monotherapy any time after the diagnosis of PoPH. A minimum duration of treatment or minimum dose was not prespecified.

\section{Outcome}

mPAP and PVR are commonly used to assess hemodynamics and liver transplantation mortality risk in PoPH (16). An mPAP between $35 \mathrm{mmHg}$ and $50 \mathrm{mmHg}$, in addition to a PVR $\geq 250 \mathrm{dyn} \cdot \mathrm{s} \cdot \mathrm{cm}^{-5}$, has been associated with a $50 \%$ mortality rate following liver transplantation (16). Because PVR encompasses both pulmonary pressure and cardiac output, the authors elected to use change in PVR after six months of PDE5 inhibitor monotherapy as the primary outcome measure. Secondary outcomes were change in PVR after 12 and 24 months, change in mPAP, cardiac output, PCWP, WHO functional class, plasma-brain natriuretic peptide (BNP) level, 6 min walk distance (6-MWD), and safety outcomes after six, 12 and 24 months of PDE5 inhibitor monotherapy. Safety outcomes included headache, flushing, dyspepsia, gastritis, back pain, loose stools, limb pain or myalgias, cough, epistaxis, pyrexia, insomnia and visual disturbance (11). Time to death (all-cause mortality) or transplantation (liver, lung or both) was evaluated. Patients alive on January 1, 2012 were censored. Dates of death were obtained from the clinic chart, electronic medical record or obituary. The date of death was used from the obituary if there was a correct match on at least four of six of first name, last name, date of birth or age at death, location (city/town), timing (after last clinic visit) and use of the terms 'portopulmonary hypertension' or 'pulmonary hypertension' in the obituary. This method of obtaining vital data has been successfully implemented in other studies (17).

\section{Data collection and administration}

A single abstracter (JHF) obtained data from charts and hospital electronic records using a standardized abstraction form. The date of birth, sex, dates of liver disease and $\mathrm{PoPH}$ diagnosis, etiology of liver disease, date of PDE5 inhibitor initiation, comorbidities, treatments, functional class, hemodynamic measures, BNP level, 6-MWD, Child-Pugh score, model for end-stage liver disease score, dates of death, lung or liver transplant and safety outcomes were recorded.

Data were double-entered into a computerized database. The duplicate files were cross-referenced for discordant data points to minimize data entry error. All discordant data points were verified against the original data abstraction form.

\section{Statistical analysis}

Descriptive statistics were used to summarize the data. The Wilcoxon matched pairs signed-rank test was used evaluate mean differences in hemodynamic parameters. WHO functional class was dichotomized as classes I and II versus classes III and IV. Pearson's $\chi^{2}$ test with Yates' continuity correction were used to evaluate differences in proportions. Survival was evaluated using Kaplan-Meier functions. Using Bonferroni
TABLE 1

Baseline echocardiographic findings in two individuals with elevated pulmonary capillary wedge pressure (PCWP)

\begin{tabular}{lll}
\hline & \multicolumn{2}{c}{ Patient } \\
\cline { 2 - 3 } & $\mathbf{1}$ (PCWP 22 $\mathbf{~ m H g})$ & $\mathbf{2}$ (PCWP 16 $\mathbf{~ m H g )}$ \\
\hline LV function & Normal & Normal \\
LA size & Mildly enlarged & Enlarged (severity not listed) \\
Mitral valve & Mild regurgitation & Mild regurgitation \\
Aortic valve & No stenosis or regurgitation & No stenosis or regurgitation \\
RV function & Severely reduced & Normal \\
RV size & Severely enlarged & Moderately enlarged \\
RA size & Severely enlarged & Enlarged (severity not listed) \\
Tricuspid & Mild to moderate regurgitation & Moderate regurgitation \\
valve & & \\
RVSP & 98 mmHg & 55 mmHg \\
\hline
\end{tabular}

LA Left atrium; LV Left ventricle; RA Right atrium; RV Right ventricle; RVSP $R V$ systolic pressure

correction to account for multiple comparisons, $\mathrm{P} \leq 0.003$ was considered to be statistically significant. A sensitivity analysis was conducted for change in PVR using the mean PVR at six months to impute for missing data. Analyses were performed using RStudio version 0.97.248 (RStudio, USA).

\section{RESULTS}

\section{Patients}

A review of 1385 patients seen at the University Health Network Pulmonary Hypertension Program identified 25 patients with PoPH. Twenty $(80 \%)$ were treated with a PDE5 inhibitor. Of these, two patients had a PCWP $>15 \mathrm{mmHg}$ on diagnostic right heart catheterization $(22 \mathrm{mmHg}$ and $16 \mathrm{mmHg}$ ); however, the transpulmonary gradient was significantly increased in both $(40 \mathrm{mmHg}$ and $21 \mathrm{mmHg}$, respectively) and they were subsequently included in the analysis. Echocardiographic findings are shown in Table 1. The initial therapy was sildenafil $20 \mathrm{mg}$ three times daily in 15 patients, sildenafil $25 \mathrm{mg}$ three times daily in four patients and tadalafil $40 \mathrm{mg}$ daily in one patient. The median time from diagnosis of $\mathrm{PoPH}$ to initiation of PDE5 inhibitor was two months (interquartile range one to three months). One patient received 11 days of inhaled epoprostenol sodium (Flolan, GlaxoSmithKline, USA) initiated at the same time as tadalafil. Given the short duration of therapy, the authors believed that the inhaled Flolan was unlikely to impact six-month PVR and, thus, this patient was included in the primary analysis. No other patients received prostaglandin analogues or endothelin receptor antagonists. Physician explanations for not initiating a PDE5 inhibitor in the untreated group included: $\mathrm{PoPH}$ was too mild $(\mathrm{n}=2)$; awaiting approval for starting therapy in a trial $(\mathrm{n}=2)$; and not a candidate for vasodilator therapy $(n=1)$. The authors were unable to firmly determine why this one patient was believed not to be a candidate for vasodilator therapy by the treating physician. Baseline characteristics of the treated and untreated groups are summarized in Table 2. More patients were male $(60 \%$ in the treated group and $80 \%$ in the untreated group) and the most common etiology of liver disease was alcohol use $(55 \%$ in the treated group and $60 \%$ in the untreated group). Less common etiologies for liver disease were congenital hepatic fibrosis $(n=1)$, diffuse biliary strictures post transplant $(n=1)$, combined alcohol and hepatitis $C(n=1)$, and combined alcohol and hemochromatosis $(n=1)$ in the treated group and cryptogenic $(n=1)$ in the untreated group. Four patients in the treated group had mild chronic obstructive pulmonary disease that was not believed to be sufficient to cause PAH. Forced expiratory volume in $1 \mathrm{~s}\left(\mathrm{FEV}_{1}\right)$ was normal in three of these patients. The fourth patient had a concomitant restriction, with an $\mathrm{FEV}_{1}$ of $1.65 \mathrm{~L}$ (63\%), forced vital capacity (FVC) of $2.86 \mathrm{~L}^{(63 \%)}$ and $\mathrm{FEV}_{1} / \mathrm{FVC}$ ratio of 67 . The restriction was believed to be possibly related to obesity (body mass index $34.7 \mathrm{~kg} / \mathrm{m}^{2}$ ), 
TABLE 2

Patient baseline characteristics

\begin{tabular}{|c|c|c|}
\hline Baseline characteristics & Untreated $(n=5)$ & Treated $(n=20)$ \\
\hline Male sex & $4(80)$ & $12(60)$ \\
\hline $\begin{array}{l}\text { Age at pulmonary hypertension } \\
\text { diagnosis, years, median (IQR) }\end{array}$ & $58(55,60)$ & $55(47.5,60.5)$ \\
\hline $\begin{array}{l}\text { Age at liver disease diagnosis, } \\
\text { years, median (IQR) }\end{array}$ & $49(43.3,55.8)$ & $47(39,52.5)$ \\
\hline \multicolumn{3}{|l|}{ Etiology of liver disease } \\
\hline Alcohol & $3(60)$ & $11(55)$ \\
\hline $\mathrm{NASH}$ & $0(0)$ & $2(10)$ \\
\hline Viral hepatitis & $1(20)$ & $2(10)$ \\
\hline Autoimmune & $0(0)$ & $1(5)$ \\
\hline Other & $1(20)$ & $4(20)$ \\
\hline MELD score, median (IQR) & $14(11,15)$ & $15(13,18)$ \\
\hline \multicolumn{3}{|l|}{ Child-Pugh class } \\
\hline A & $1(20)$ & $3(15)$ \\
\hline B & $1(20)$ & $7(35)$ \\
\hline C & $1(20)$ & $3(15)$ \\
\hline Not available & $2(40)$ & $7(35)$ \\
\hline \multicolumn{3}{|l|}{ Comorbidities } \\
\hline Coronary artery disease & $0(0)$ & $4(20)$ \\
\hline Systemic hypertension & $3(60)$ & $9(45)$ \\
\hline Diabetes mellitus & $1(20)$ & $8(40)$ \\
\hline Hyperlipidemia & $1(20)$ & $6(30)$ \\
\hline Peripheral vascular disease & $0(0)$ & $0(0)$ \\
\hline Cancer & $0(0)$ & $5(25)$ \\
\hline Chronic obstructive pulmonary disease & $1(20)$ & $4(20)$ \\
\hline Chronic kidney disease & $0(0)$ & $1(5)$ \\
\hline Congestive heart failure & $0(0)$ & $1(5)$ \\
\hline Beta blocker use & $2(40)$ & $7(35)$ \\
\hline
\end{tabular}

Data presented as $n(\%)$ unless otherwise indicated. IQR Interquartile range; MELD Model for end-stage liver disease; NASH Nonalcoholic steatohepatitis

with no other etiology identified. Computed tomography of the chest did not show any significant parenchymal lung disease. Baseline hemodynamic parameters for both groups are outlined in Table 3.

\section{Primary outcome}

Nineteen of 20 treated patients underwent a follow-up right heart catheterization after PDE5 inhibitor initiation (17 at six months, one at 12 months and one at 24 months); one patient in the treated group died before their scheduled right heart catheterization, and the authors were unable to determine the cause of death. One patient in the treated group underwent a right heart catheterization at six, 12 and 24 months. Only one untreated patient underwent a follow-up right heart catheterization. After six months of PDE5 inhibitor therapy, there was a significant decrease in mean PVR by $-236 \mathrm{dyn} \cdot \mathrm{s} \cdot \mathrm{cm}^{-5}$ $\left(95 \%\right.$ CI -343 dyn $\bullet \cdot \bullet \mathrm{cm}^{-5}$ to -130 dyn $\left.\bullet \cdot \cdot \mathrm{cm}^{-5} ; \mathrm{P}<0.001\right)$. A sensitivity analysis using the mean six-month PVR to impute for missing data improved the precision but did not change the magnitude of the treatment effect (mean change in PVR -209 dyn $\bullet \cdot \cdot \mathrm{cm}^{-5}$ [95\% CI $-304 \mathrm{dyn} \cdot \mathrm{s} \cdot \mathrm{cm}^{-5}$ to $-115 \mathrm{dyn} \cdot \mathrm{s} \cdot \mathrm{cm}^{-5}$ ]; $\left.\mathrm{P}<0.001\right)$. One patient in the treated group had worsening in PVR at six months (Figure 1).

\section{Secondary outcomes}

Improvements were also observed in other hemodynamic parameters in the treated group on six-month follow-up right heart catheterization (Table 3). There was no significant change in PCWP. Hemodynamic data were available for only two patients at 12 and 24 months (Table 4). Individual PVR response is shown in Figure 1. The mean $( \pm \mathrm{SD})$ plasma BNP level was $134.6 \pm 83.1 \mathrm{pg} / \mathrm{mL}$ at baseline $(\mathrm{n}=10)$ and significantly decreased after six months of PDE5 inhibitor therapy (mean difference $-51.9 \mathrm{pg} / \mathrm{mL}[95 \% \mathrm{CI}-94.6 \mathrm{pg} / \mathrm{mL}$ to $-9.2 \mathrm{pg} / \mathrm{mL}] ; \mathrm{P}=0.02, \mathrm{n}=10)$. The

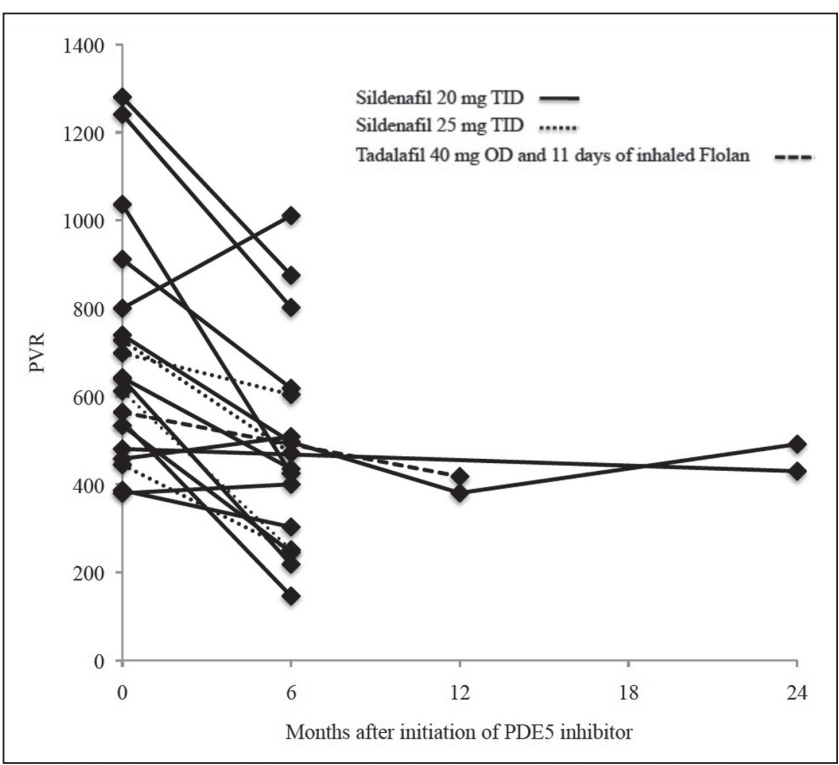

Figure 1) Individual pulmonary vascular resistance (PVR) response to phosphodiesterase-5 (PDE5) inhibitors. X-axis represents time after PDE5 inhibitor initiation; $y$-axis represents PVR expressed as dyn $\bullet \cdot \cdot \mathrm{cm}^{-5}$. TID Three times daily; OD Once daily. Flolan GlaxoSmithKline, USA

improvements in plasma BNP level were sustained but not statistically significant at 12 and 24 months (mean difference $-63.0 \mathrm{pg} / \mathrm{mL}$ [95\% CI $-137.6 \mathrm{pg} / \mathrm{mL}$ to $11.6 \mathrm{pg} / \mathrm{mL}$ ]; $\mathrm{P}=0.07, \mathrm{n}=8$; and $-29.6 \mathrm{pg} / \mathrm{mL}[95 \% \mathrm{CI}$ $-159.4 \mathrm{pg} / \mathrm{mL}$ to $100.1 \mathrm{pg} / \mathrm{mL}$; $\mathrm{P}=0.42, \mathrm{n}=6$, respectively).

There was an improvement in symptoms observed after PDE5 inhibitor initiation, with the proportion of subjects with a WHO functional class of III or IV significantly less at six months compared with baseline ( $18 \%$ versus $61 \% ; \mathrm{P}=0.002)$. There was no significant change in 6-MWD at six, 12 or 24 months (mean difference $6.9 \mathrm{~m}$ [95\% CI $-31.2 \mathrm{~m}$ to $45.0 \mathrm{~m} ; \mathrm{P}=0.69, \mathrm{n}=16] ; 18.0 \mathrm{~m}$ [95\% CI $-21.6 \mathrm{~m}$ to $57.6 \mathrm{~m} ; \mathrm{P}=0.33, \mathrm{n}=15]$; and $4.0 \mathrm{~m}[95 \% \mathrm{CI}-70.2 \mathrm{~m}$ to $78.2 \mathrm{~m} ; \mathrm{P}=0.89$, $\mathrm{n}=12]$, respectively).

\section{Safety}

PDE5 inhibitors were well tolerated by the study cohort; dyspepsia, loose stools, back pain and myalgias were the only observed side effects and occurred in $<10 \%$ of patients. No serious medication-related adverse events were observed; however, the cause of death for the patient who died before undergoing a follow-up right heart catheterization was indeterminable.

\section{Survival}

Survival status as of January 1, 2012 was determined for all study patients. The probability of one-year survival was $84.4 \%$ (95\% CI $70 \%$ to $100 \%$ ), two-year survival was $72 \%$ (95\% CI $53 \%$ to $97 \%$ ) and fouryear survival was $57 \%$ (95\% CI 34\% to 97\%). One patient in the treated group was able to undergo successful liver transplant after PDE5 inhibitor initiation; however, five patients went from being considered to be 'inoperable' to 'operable' based on hemodynamic criteria ( $\mathrm{mPAP}<35 \mathrm{mmHg}$ and PVR $<250 \mathrm{mmHg}$ ). In the transplanted patient, echocardiogram subsequently showed normalization of right ventricular systolic pressure and the PDE5 inhibitor was discontinued one-year post-transplant. The patient remained alive at the time of censoring ( 2.5 years post-liver transplant) with no indication of PAH recurrence.

\section{DISCUSSION}

We found that PDE5 inhibitor therapy improved hemodynamics, BNP levels and WHO functional class after six months. PDE5 inhibitors were well tolerated by our study cohort, with no major adverse events 
TABLE 3

Hemodynamic data at baseline and six months post-phosphodiesterase-5 inhibitor treatment

\begin{tabular}{|c|c|c|c|c|}
\hline \multirow[b]{2}{*}{ Outcome } & \multicolumn{2}{|c|}{ Baseline } & \multicolumn{2}{|c|}{ Six months (treated [n=17]) } \\
\hline & Untreated $(n=5)$ & Treated $(n=20)$ & Mean difference $(95 \% \mathrm{Cl})$ & $\mathbf{P}$ \\
\hline Pulmonary vascular resistance, dyn $\cdot \mathrm{s} \cdot \mathrm{cm}^{-5}$ & $450.7 \pm 212.7$ & $683.3 \pm 259.0$ & $-236.1(-342.6$ to -129.6$)$ & $<0.001$ \\
\hline Mean pulmonary aretery pressure, $\mathrm{mmHg}$ & $38.4 \pm 11.8$ & $47.5 \pm 10.2$ & $-8.9(-13.7$ to -4.2$)$ & 0.001 \\
\hline Pulmonay capillary wedge pressure, $\mathrm{mmHg}$ & $10.8 \pm 4.8$ & $10 \pm 5.9$ & $0.1(-3.2$ to 3.4$)$ & 0.94 \\
\hline
\end{tabular}

Data presented mean \pm SD unless otherwise indicated

TABLE 4

Individual hemodynamic data in the treated group at baseline, 12 and 24 months post-phosphodiesterase inhibitor treatment

\begin{tabular}{|c|c|c|c|c|c|c|c|c|c|}
\hline \multirow[b]{2}{*}{ Outcome } & \multicolumn{3}{|c|}{ Patient 1} & \multicolumn{3}{|c|}{ Patient 2} & \multicolumn{3}{|c|}{ Patient 3} \\
\hline & Baseline & 12 month & 24 months & Baseline & 12 months & 24 months & Baseline & 12 months & 24 months \\
\hline $\mathrm{mPAP}, \mathrm{mmHg}$ & 46 & 33 & 33 & 46 & - & 40 & 34 & 34 & - \\
\hline PCWP, mmHg & 1 & 4 & 5 & 14 & - & 9 & 3 & 8 & - \\
\hline
\end{tabular}

mPAP Mean pulmonary artery pressure; PCWP Pulmonary capillary wedge pressure; PVR Pulmonary vascular resistance

observed. To our knowledge, this is one of the largest cohorts to date investigating PDE5 inhibitor monotherapy in patients with PoPH. Previously published case reports have described the use of PDE5 inhibitors in $\mathrm{PoPH}$ as both targeted therapy and a bridge to liver transplant. Bremer et al (18) published a case report involving a 55-year-old man with $\mathrm{PoPH}$ who had a sustained reduction in pulmonary and portal pressures at six months with the use of tadalafil followed by maintenance sildenafil. Makisalo et al (19) described the use of sildenafil in a cirrhotic patient with severe $\mathrm{PoPH}$ as a bridge to liver transplant. This patient had a reduction in pulmonary pressures to a level that allowed for a successful liver transplant, which had previously been considered to be contraindicated. Hollatz et al (20) described a group of 11 patients with $\mathrm{PoPH}$ that underwent successful liver transplant after treatment with primarily sildenafil and/or subcutaneous treprostinil. Seven patients had been started initially on sildenafil monotherapy; however, five eventually had a second agent added. Another observational study followed 14 patients with moderate to severe PoPH who were treated with sildenafil (21). However, only eight of these patients received sildenafil as monotherapy and the remaining six were treated with inhaled prostaglandin analogue therapy with the subsequent addition of sildenafil. In the 12 patients who completed the study, 6-MWD was improved at both three months and one year. A reduction in PVR and mPAP was shown in a group of nine patients after treatment with sildenafil for variable durations (22).

The magnitude of the treatment effect observed on change in PVR in our study was similar to that reported in randomized control trial data of sildenafil for the treatment of other causes of WHO group $1 \mathrm{PAH}(11)$ and two previous small observational studies in patients with PoPH (20-22). However, direct comparison of our study to previous observational data is difficult because many of the patients in other studies received combination therapy rather than a PDE5 inhibitor alone. One patient exhibited worsening in PVR after six months of therapy. We are unable to explain the lack of response in this individual. Time from diagnosis of $\mathrm{PoPH}$ to initiation of PDE5 inhibitor was four months, making it possible that PVR worsened before starting therapy. The patient did continue to consume alcohol; however, follow-up data on liver disease severity were unavailable. Sildenafil has been shown to significantly improve 6-MWD in patients with other causes of WHO group 1 PAH (11), but the effect on 6-MWD in patients with PoPH has varied among different studies $(20,21,23)$. We did not show a significant improvement in 6-MWD with PDE5 inhibitor therapy; however, there was no decline over 24 months, suggesting at the very least that patients did not experience worsening in their exercise capacity. Again, a direct comparison of treatment effect on 6-MWD between our study and previous data is problematic, given that many patients in previous studies received an additional therapy, including epoprostenol, iloprost, treprostinil and/ or bosentan $(20,21)$. In the study that reported a significant improvement in 6-MWD, the baseline PVR was $387 \mathrm{dyn} \cdot \mathrm{s} \cdot \mathrm{cm}^{-5}$ higher and baseline 6-MWD was $73 \mathrm{~m}$ less than in our cohort, which may partially account for the different result (21). Furthermore 6-MWD improvements may be difficult to demonstrate in some patients with $\mathrm{PoPH}$, given the potential coexistence of ascites, deconditioning, sarcopenia, anemia and encephalopathy, which may affect 6-MWD independent of hemodynamic changes.

Survival at two years in our study cohort was similar to that reported in PoPH patients enrolled in The Registry to EValuate Early And Long-term pulmonary arterial hypertension disease management (REVEAL) (6), and better than that previously described in a group of untreated patients (4). However, survival estimates vary widely among studies, ranging between $14 \%$ and $68 \%$ at five years, depending on the cohort and whether patients received any targeted PAH treatments or liver transplant $(24,25)$.

There were several limitations to our study. Given that this was a retrospective observational study, we were at risk for selection bias and untreated patients may be systematically different from the patients who received therapy. Only patients with private insurance, compassionate coverage from the drug company or government, or the ability to pay out of pocket were started on treatment. There may be important unmeasured characteristics that differ between such individuals and those who do not have drug coverage or the ability to pay, thus potentially altering outcomes. Interestingly, the untreated group had lower baseline PVR and were slightly older than the treated group. It is unclear whether response to therapy would be different in this population. We did not have follow-up hemodynamic data on untreated patients and, thus, did not have a control group for comparison. Hemodynamic data at 12 and 24 months were only available for two patients. We were also unable to determine cause of death. Although the use of endothelin inhibitors in PoPH has been evaluated (26), we were concerned that these agents were potentially hepatotoxic. Therefore, we do not have comparator data to this class of medications, nor did we evaluate the effects of combination oral therapy in our cohort. Despite this, our study results are encouraging, suggesting that patients with PoPH may derive significant benefit from PDE5 inhibitor therapy. The extent to which treatment improves eligibility or outcomes in liver transplantation remains unclear.

The French Registry cohort of patients with PAH (27) suggests that $\mathrm{PoPH}$ is not uncommon and accounts for approximately $10 \%$ of PAH cases. However, data regarding treatment with targeted PAH therapies in this group of patients are limited and, in Canada, there are no formally approved medications. The subsequent decision to initiate therapy, as well as the patient's ability to pay for nonapproved medications is, 
therefore, quite problematic. PDE5 inhibitors are an attractive first-line therapy in patients with $\mathrm{PoPH}$ given the ease of administration and lack of hepatotoxicity and edema that can be observed with other PAH therapies (10,28-30). In addition, genetic polymorphisms in PDE5 have been associated with an increased risk for $\mathrm{PoPH}$, lending support to the use of therapies targeting cyclic GMP (31). However, a randomized controlled trial of such targeted therapy is lacking and clearly needed in this group of patients.

We found that PDE5 inhibitor therapy was well tolerated and improved PVR, mPAP and WHO functional class in a cohort of patients with PoPH. A randomized controlled trial is needed to confirm efficacy and safety in this patient population.

ACKNOWLEDGEMENTS: Author contributions: Dr Fisher contributed to the concept and design, analysis and interpretation of data, and drafting and approval of the manuscript. Dr Johnson contributed to the

\section{REFERENCES}

1. Rodriguez-Roisin R, Krowka MJ, Herve P, Fallon MB. Pulmonaryhepatic vascular disorders (PHD). Eur Respir J 2004;24:861-80.

2. Simonneau G, Robbins IM, Beghetti M, et al. Updated clinical classification of pulmonary hypertension. J Am Coll Cardiol 2009;54:S43-54.

3. Edwards BS, Weir EK, Edwards WD, Ludwig J, Dykoski RK, Edwards JE. Coexistent pulmonary and portal hypertension: Morphologic and clinical features. J Am Coll Cardiol 1987;10:1233-8.

4. Robalino BD, Moodie DS. Association between primary pulmonary hypertension and portal hypertension: Analysis of its pathophysiology and clinical, laboratory and hemodynamic manifestations. J Am Coll Cardiol 1991;17:492-8.

5. Krowka MJ, Miller DP, Barst RJ, et al. Portopulmonary hypertension: A report from the US-based REVEAL registry. Chest 2012;141:906-15.

6. Kawut SM, Taichman DB, Ahya VN, et al. Hemodynamics and survival of patients with portopulmonary hypertension. Liver Transpl 2005;11:1107-11.

7. Ramsay MA, Simpson BR, Nguyen AT, Ramsay KJ, East C, Klintmalm GB. Severe pulmonary hypertension in liver transplant candidates. Liver Transpl Surg 1997;3:494-500.

8. Barst RJ, Rubin LJ, McGoon MD, Caldwell EJ, Long WA, Levy PS. Survival in primary pulmonary hypertension with long-term continuous intravenous prostacyclin. Ann Intern Med 1994;121:409-15.

9. Barst RJ, Rubin LJ, Long WA, et al. A comparison of continuous intravenous epoprostenol (prostacyclin) with conventional therapy for primary pulmonary hypertension. N Engl J Med 1996;334:296-301.

10. Rubin LJ, Badesch DB, Barst RJ, et al. Bosentan therapy for pulmonary arterial hypertension. N Engl J Med 2002;346:896-903.

11. Galie N, Ghofrani HA, Torbicki A, et al. Sildenafil citrate therapy for pulmonary arterial hypertension. N Engl J Med 2005;353:2148-57.

12. Pepke-Zaba J, Gilbert C, Collings L, Brown MC. Sildenafil improves health-related quality of life in patients with pulmonary arterial hypertension. Chest 2008;133:183-9.

13. Galie N, Brundage BH, Ghofrani HA, et al. Tadalafil therapy for pulmonary arterial hypertension. Circulation 2009;119:2894-903.

14. Badesch DB, Champion HC, Sanchez MA, et al. Diagnosis and assessment of pulmonary arterial hypertension. J Am Coll Cardiol 2009;54:S55-66.

15. Galie N, Hoeper MM, Humbert M, et al. Guidelines for the diagnosis and treatment of pulmonary hypertension. Eur Respir J 2009;34:1219-63.

16. Krowka MJ, Plevak DJ, Findlay JY, Rosen CB, Wiesner RH, Krom RA. Pulmonary hemodynamics and perioperative cardiopulmonaryrelated mortality in patients with portopulmonary hypertension undergoing liver transplantation. Liver Transpl 2000;6:443-50. concept and design, analysis and interpretation of data, and revision and approval of the manuscript. Ms Chau contributed to study administration, data collection, cleaning and analysis, and revision and approval of the manuscript. Ms Kron contributed to study administration, data collection, cleaning and analysis, and revision and approval of the manuscript. Dr Granton contributed to the concept and design, interpretation of data, and revision and approval of the manuscript.

DISCLOSURES: Dr Granton has received an unrestricted grant from Pfizer/CIHR to conduct a controlled clinical trial of sildenafil in the treatment of portal pulmonary hypertension. He has served as a consultant for Actelion, Lilly, Bayer and Pfizer pharmaceuticals. All income from this activity is directed toward the University Health Network Foundation. The other authors have no relevant financial disclosures or potential conflicts of interest to declare.

17. Johnson SR, Granton JT, Tomlinson GA, et al. Warfarin in systemic sclerosis-associated and idiopathic pulmonary arterial hypertension. A bayesian approach to evaluating treatment for uncommon disease. J Rheumatol 2012;39:276-285.

18. Bremer HC, Kreisel W, Roecker K, et al. Phosphodiesterase 5 inhibitors lower both portal and pulmonary pressure in portopulmonary hypertension: A case report. J Med Case Rep 2007;1:46.

19. Makisalo H, Koivusalo A, Vakkuri A, Hockerstedt K. Sildenafil for portopulmonary hypertension in a patient undergoing liver transplantation. Liver Transpl 2004;10:945-50.

20. Hollatz TJ, Musat A, Westphal S, et al. Treatment with sildenafil and treprostinil allows successful liver transplantation of patients with moderate to severe portopulmonary hypertension. Liver Transpl 2012;18:686-95.

21. Reichenberger F, Voswinckel R, Steveling E, et al. Sildenafil treatment for portopulmonary hypertension. Eur Respir J 2006;28:563-7.

22. Gough MS, White RJ. Sildenafil therapy is associated with improved hemodynamics in liver transplantation candidates with pulmonary arterial hypertension. Liver Transpl 2009;15:30-6.

23. Hemnes AR, Robbins IM. Sildenafil monotherapy in portopulmonary hypertension can facilitate liver transplantation. Liver Transpl 2009;15:15-9.

24. Le Pavec J, Souza R, Herve P, et al. Portopulmonary hypertension: Survival and prognostic factors. Am J Respir Crit Care Med 2008;178:637-43.

25. Swanson KL, Wiesner RH, Nyberg SL, Rosen CB, Krowka MJ. Survival in portopulmonary hypertension: Mayo clinic experience categorized by treatment subgroups. Am J Transplant 2008;8:2445-53.

26. Savale L, Magnier R, Le Pavec J, et al. Efficacy, safety, and pharmacokinetics of bosentan in portopulmonary hypertension. Eur Respir J 2013;41:96-103.

27. Humbert M, Sitbon O, Chaouat A, et al. Pulmonary arterial hypertension in France: Results from a national registry. Am J Respir Crit Care Med 2006;173:1023-30.

28. Lee WT, Kirkham N, Johnson MK, Lordan JL, Fisher AJ, Peacock AJ. Sitaxentan-related acute liver failure in a patient with pulmonary arterial hypertension. Eur Respir J 2011;37:472-4.

29. Lavelle A, Sugrue R, Lawler G, et al. Sitaxentan-induced hepatic failure in two patients with pulmonary arterial hypertension. Eur Respir J 2009;34:770-1.

30. Hoeper MM, Olsson KM, Schneider A, Golpon H. Severe hepatitis associated with sitaxentan and response to glucocorticoid therapy. Eur Respir J 2009;33:1518-9.

31. Roberts KE, Fallon MB, Krowka MJ, et al. Genetic risk factors for portopulmonary hypertension in patients with advanced liver disease. Am J Respir Crit Care Med 2009;179:835-42. 


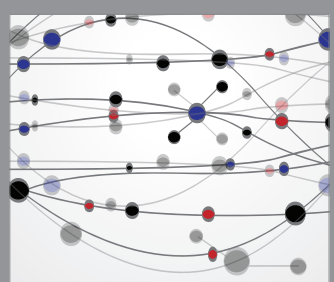

The Scientific World Journal
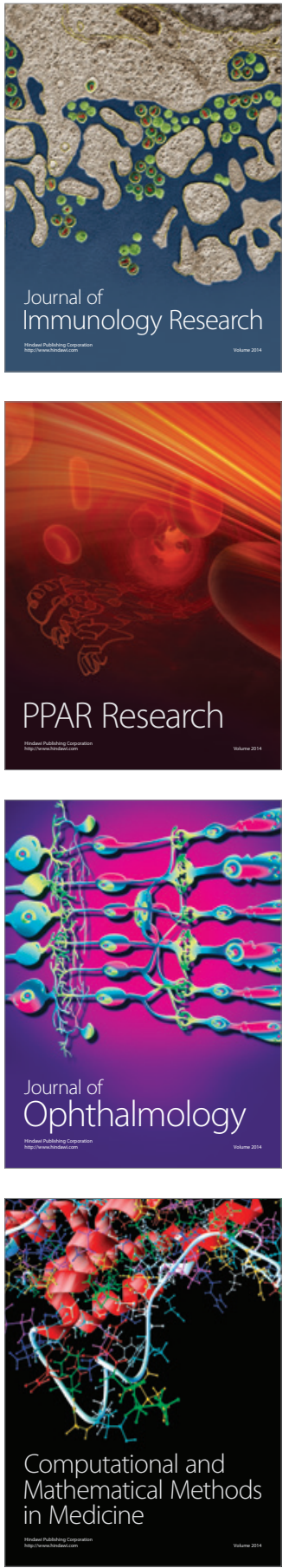

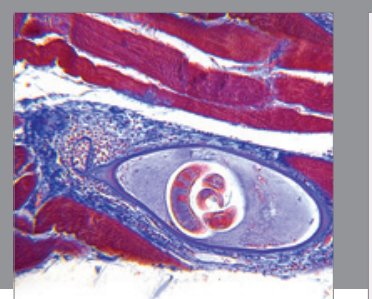

Gastroenterology Research and Practice

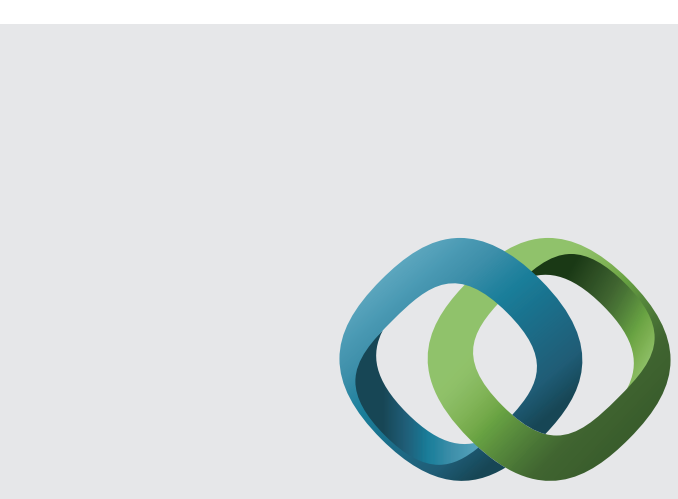

\section{Hindawi}

Submit your manuscripts at

http://www.hindawi.com
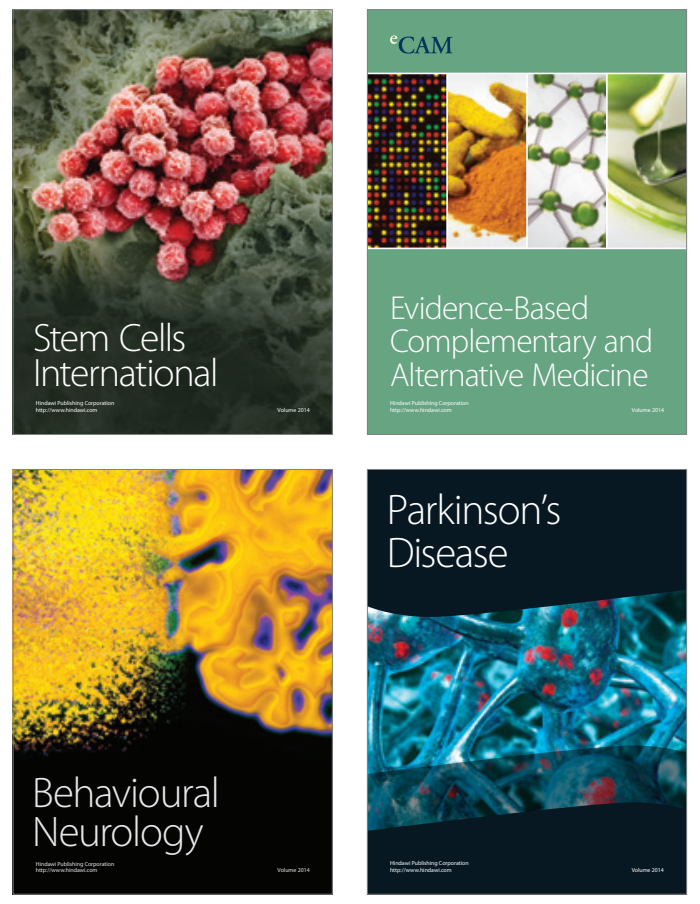
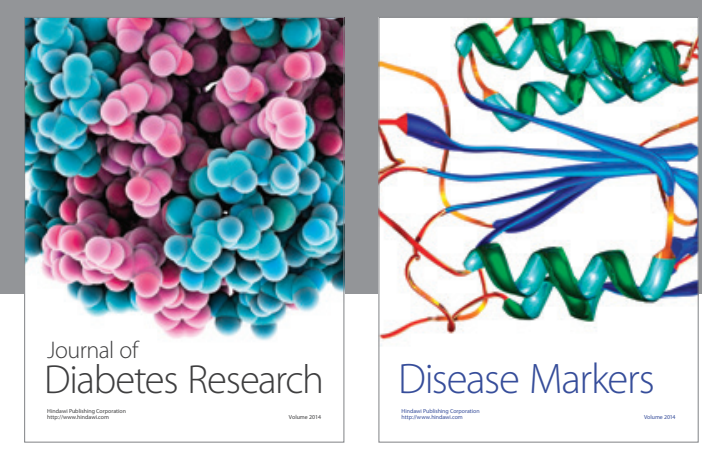

Disease Markers
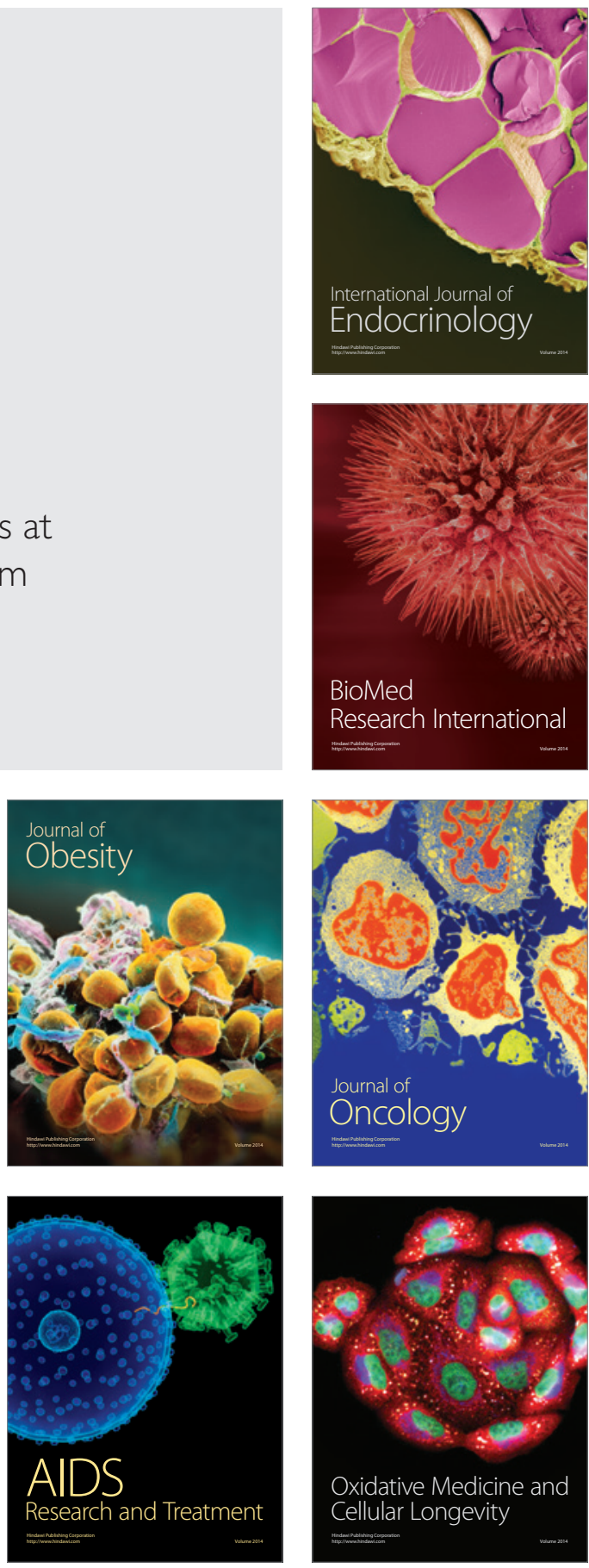